\title{
New floristic records of benthic diatoms (Bacillariophyceae) from the Gulf of California
}

\section{Nuevos registros florísticos de diatomeas bentónicas (Bacillariophyceae) del golfo de California}

\author{
Yuriko Jocselin Martínez and David Alfaro Siqueiros-Beltrones
}

Departamento de Plancton y Ecología Marina, Centro Interdisciplinario de Ciencias Marinas, Instituto Politécnico Nacional. Av. IPN s/n, Col. Playa Palo de Santa Rita, La Paz,

Aceptado: 24 de enero de 2018

Martínez Y. J. and D. A. Siqueiros-Beltrones. 2018. New floristic records of benthic diatoms (Bacillariophyceae) from the Gulf of California. Hidrobiológica 28 (1): $141-145$. D0l: 10.24275/uam/izt/dcbs/hidro/2018v28n1/Siqueiros

\begin{abstract}
Background. Most studies on benthic diatoms found in northwestern Mexico have been done along the western coast of the Baja California peninsula. Thus, few studies exist for the Gulf of California. Goals. To gather new records of benthic diatoms found in the Gulf of California. Methods. Diatom samples from sediments and rocks of the coast of Santa Rosalía, Baja California Sur, were observed under a light microscope (LM). Results. Three taxa were recorded and depicted: Caloneis liber var. bicuneata (common), Gyrosigma naja (scarce), and the new combination Entomoneis pulchra var. pulchella (scarce). Conclusions. These three taxa were recorded for the first time in northwestern Mexico.
\end{abstract}

Keywords: Amphiprora, comb. nov., epilithic, epipelic, northwestern Mexico

\section{RESUMEN}

Antecedentes. Los estudios sobre diatomeas bentónicas para el Noroeste mexicano se han hecho principalmente para la costa occidental de la península de Baja California, pero son pocos para el golfo de California. Objetivos. Presentar nuevos registros de diatomeas bentónicas para el golfo de California. Métodos. Se observaron muestras de diatomeas de sedimentos y rocas de la costa de Santa Rosalía, Baja California Sur, México bajo el microscopio de luz. Resultados. Se registraron tres nuevos taxa: Caloneis liber var. bicuneata (común) y Gyrosigma naja (raro), y la nueva combinación Entomoneis pulchra var. pulchella (raro). Conclusiones. Estos tres taxa son registrados por primera vez para la región Noroeste de México.

Palabras clave: Amphiprora, comb. nov., epilíticas, epipélicas, Noroeste mexicano
The first floristic list of benthic marine diatoms from Mexico (LópezFuerte \& Siqueiros-Beltrones, 2016) showed that most of the taxa from Mexican littorals have been recorded for the Mexican northwestern region. Few, however, correspond to the Gulf of California coasts. Thus, there is reason to assume that a considerable number of taxa have yet to be recorded in this area.

A reliable taxonomic record of benthic diatoms for any given locality is recommended due to their ecological significance (SiqueirosBeltrones, 2002). They are an essential food-source for many benthic animals, including those of commercial importance, and their assemblages could be used as a reference to assess natural or anthropogenic environmental impact (Siqueiros-Beltrones et al., 2014). It is thus imperative to account for new records that derive from studies in surveyed and un-surveyed areas. This is especially true in Mexican littorals where new records of benthic diatom species are expected to be made in upcoming surveys, as is the case of a recent floristic survey in a lagoon located within a protected area (Siqueiros-Beltrones \& ArgumedoHernández, 2017). Accordingly, in this paper, new records are derived from a floristic survey from an allegedly contaminated beach of Santa Rosalía, Baja California Sur (Gulf of California).

Sediment and rock samples were collected during May 2015, January 2016, and March 2016 from a beach in Santa Rosalía. At this location, nine sites were chosen: five in the port area, where samples were collected at wadding depth, and two sites to the north (Punta Tanques), and two south (Cuevas) of Santa Rosalía, where samples were collected by scuba diving (Fig. 1). Sediments were collected using petri dishes $75 \mathrm{~mm}$ in diameter, and two rocks approximately $20 \times 10 \mathrm{~cm}$, devoid of macroalgae. Epilithic diatoms were collected by brushing an area of $100 \mathrm{~cm}^{2}$ from the sampled rocks. The brushed-off material and collected sediments were oxidized, following Siqueiros-Beltrones (2002) for diatom cleaning and mounting. Mounted diatoms were examined under an Olympus $\mathrm{CH}-2$ microscope at $630 \times$ and $1000 \times$. Species ref- 
erences and identification followed Cleve-Euler (1955), Hartley (1996), Péragallo and Péragallo (1908), Hein et al. (2008), Siqueiros-Beltrones (2002), and Stidolph et al. (2012).

The taxonomic status of the taxa was updated according to Guiry \& Guiry (2017; http://www.algaebase.org/search/?genus=genusname \&species=speciesname), and the Catalogue of Diatom Names of the California Academy of Sciences (CAS) web site by Fourtanier \& Kociolek (2017), http://researcharchive.calacademy.org/ research/diatoms/ names/index.asp. Also, the International Code of Nomenclature for algae, fungi, and plants (Melbourne code, McNeill et al., 2012) was consulted. Morphometric data for the new records are provided. Micrographs were taken with a CMOS Konus digital lens.

Three taxa are here depicted which are recorded for the first time in the Mexican northwestern region, including a new combination.

\section{Caloneis liber var. bicuneata (Grunow) Cleve (Figs 2A-C)}

Dimensions: Length $=50-70 \mu \mathrm{m}$; width $=8-12 \mu \mathrm{m} ; 18$ striae in $10 \mu \mathrm{m}(\mathrm{n}=5)$.

Reference: Cleve-Euler (1955), Fig. 1124b.

Occurrence: Common, found in most samples.

Synonymy: None.
Basionym: Navicula bicuneata Grunow.

Life form: Epilithic and epipsammic.

Other distribution: Seems to be distributed worldwide, Ceylon, Red Sea (Desikachary, 1988); Northern Sea (Sweden and Finland; CleveEuler, 1955); English coasts (Hartley, 1996); Galapagos Islands (Stidolph et al., 2012).

Remarks: Witkowski et al. (2000) contend that Caloneis liber var. bicuneata is a synonym of Caloneis bicuneata (Grunow) Wolle. The form they depict, however, differs from ours in having poorly lanceolate ends, a lower number of striae, and being larger. Their specimen coincides with the image in Stidolph et al. (2012), whereas ours resembles the one in Cleve-Euler (1955), Fig. 1124b. A suggestive variation for C. bicuneata is shown in Desikachary (1988), p. 5; Pl. 478, Figs. 3-6, 9.

\section{Entomoneis pulchra var. pulchella (Peragallo) Siqueiros-Beltrones et Martínez comb. nov. (Figs 2D-G).}

Dimensions: Length $=60-75 \mu \mathrm{m}$ width $=12-15 \mu \mathrm{m} ; 16$ striae in $10 \mu \mathrm{m}(\mathrm{n}=2)$.

Reference: Péragallo \& Péragallo (1908), p. 183, PI. 37, Figs. 4, 5. Occurrence: Rare, few specimens from a single site and date. Synonymy: None.

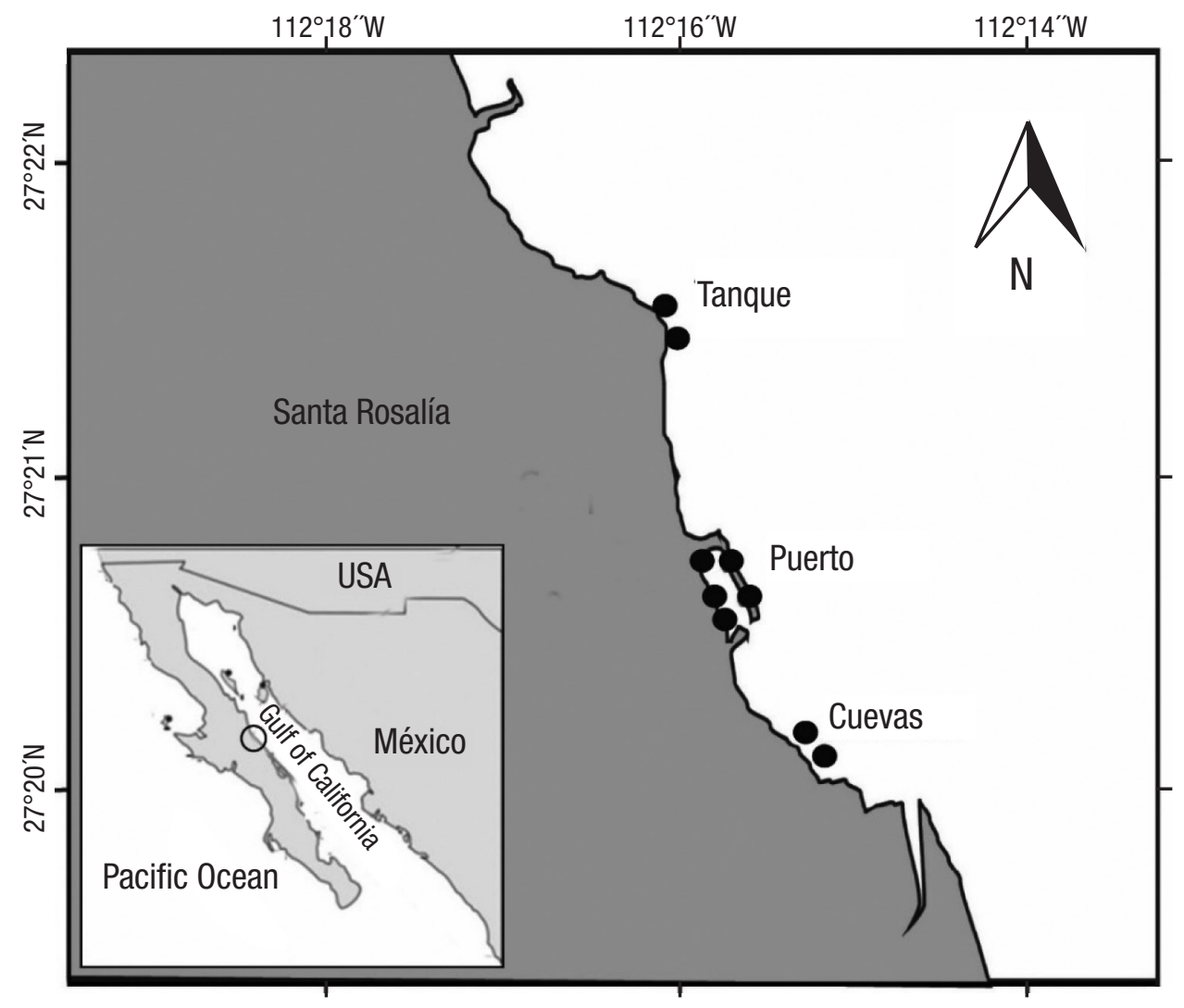

Figure 1. Location of study area and sampling sites at the Gulf of California, Mexico. 


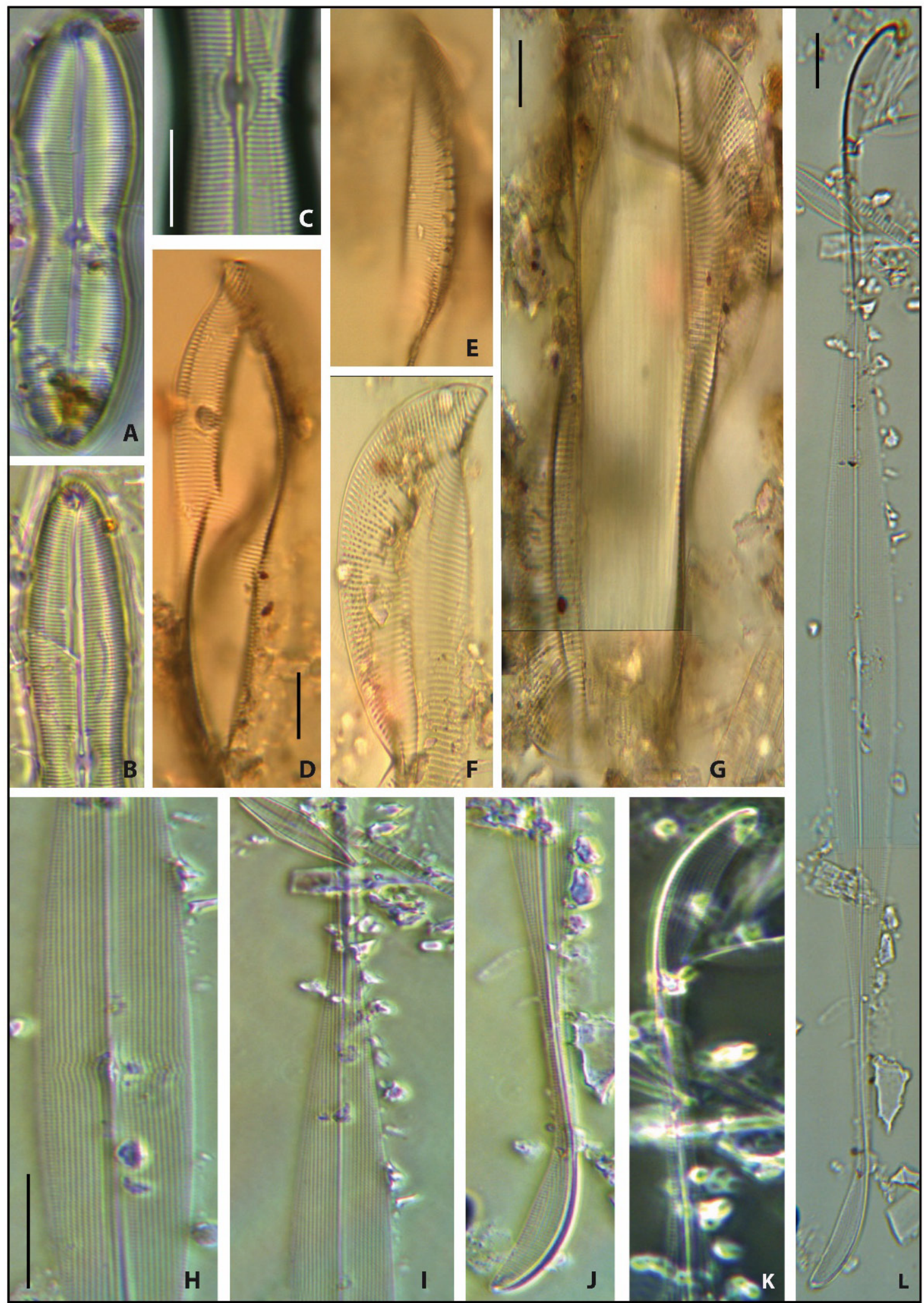

Figures 2A-L. A-C) Caloneis libervar. bicuneata (Grunow) Cleve; D-G) Entomoneis pulchra var. pulchella (Peragallo) Siqueiros-Beltrones et Martínez comb. nov.; H-L) Gyrosigma naja (Meister) Sterrenburg. A-K =1000x. L =630x. Bars $=10 \mu \mathrm{m}$. 
Basionym: Amphiprora pulchra var. pulchella Péragallo. Péragallo \& Péragallo (1908), p. 183, PI. 37, Figs. 4, 5.

Life form: Epipsammic.

Other distribution: Laguna Figueroa, B.C., México as Entomoneis alata (Siqueiros Beltrones, 2002); England and French north coast (Péragallo \& Péragallo, 1908).

Remarks: This taxon has half the length and half the number of striae in $10 \mu \mathrm{m}$ than Entomoneis pulchra (Bailey) Reimer, which has been recorded solely for the Gulf of Mexico (Licea et al., 2016). Although this new combination can be found earlier, (http://fcelter.fiu.edu/data/ database/diatom/index.htm?species=4161), its formal transference to Entomoneis is here proposed.

Slide enero 16-S4. SR Puerto (Puerto Santa Rosalía, BCS, Mexico) in the Benthic diatom scientific collection housed in CICIMAR-IPN is designated as a reference.

\section{Gyrosigma naja (Meister) Sterrenburg (Figs 2H-L)}

Dimensions: Length $=230 \mu \mathrm{m}$; width $=13 \mu \mathrm{m} ; 28$ transverse and 20 long striae in $10 \mu \mathrm{m}(n=1)$.

Reference: Sterrenburg (2000), p. 302, Figs. 5-10; Hein et al. (2008), p. 57, Pl. 31, Fig. 3.

Occurrence: Rare, both in the above reference and in the present report.

Synonymy: Gyrosigma spathulatum Ricard.

Basionym: Pleurosigma naja Meister.

Life form: Epipsammic, planktonic.

Other distribution: Indonesia (Sterrenburg, 2000), Bahamas (Hein et al., 2008).

Remarks: Contrary to previous descriptions, our specimen shows conspicuous longitudinal striae; the transverse striae pattern was almost non-discernible under LM.

No studies on benthic diatoms had hitherto been carried out for the northern eastern coasts of Baja California Sur (Gulf of California). The fact that Santa Rosalia's beach is contaminated with toxic elements, such as $\mathrm{Cu}, \mathrm{Zn}, \mathrm{Co}, \mathrm{Pb}$, and $\mathrm{Cd}$ (Jonathan et al., 2016), derived from mining activities makes it imperative to generate reliable taxonomic inventories of benthic diatoms that allow precise detection of floristic changes in order to monitor the environmental impact.

These three taxa were recorded for the first time in the Mexican northwestern region. Two of them, Entomoneis pulchra var. pulchella and Gyrosigma naja had a rare occurrence in sediments from a single sampling locality and date (in the port in January 2016) out of 18 rock samples and nine sediment samples. The former taxon was transferred to the genus Entomoneis from Amphiprora, following Péragallo \& Péragallo (1908), where A. pulchra Bailey and $A$. pulchra var. pulchella are depicted. The latter (G. naja), was described by Sterrenburg (2000) who transferred it from the genus Pleurosigma to Gyrosigma, while considering it a rare taxon. In contrast, Caloneis liber var. bicuneata was found on rocks and in sediments; it occurred commonly in all samplings. Whether these new records and their scarcity could be related to any environmental condition of the study area will be determined in the near future; the fact is that these three taxa are reported for the first time for the Mexican northwestern region.

\section{ACKNOWLEDGEMENTS}

We acknowledge F.0. López-Fuerte for his remarks on taxonomic formality and the reviews by the anonymous referees that helped to improve this manuscript.

\section{REFERENCES}

Cleve-Euler, A. 1955. Die diatomeen von Schweden und Finnland. Kungl. Svenska Vetenskapsakademiens Handlingar. Band 5, Teil IV. Stockholm. 232 p.

DesiKaChaRy, T.V. 1988. Atlas of diatoms; Marine diatoms of the Indian Ocean, Fasc. V. Madras Science Foundation. Madras. 13 p.

Fourtanier, E. \& J. P. Kociolek. 2017. Catalogue of Diatom Names of the California Academy of Sciences (CAS). Available on line at: http:// researcharchive.calacademy.org/ (downloaded on August 2017).

GuIRY, M. D. \& G. M. GuIRy. 2017. Algaebase. World-wide electronic publication. National University of Ireland, Galway. Available online at: http://www.algaebase.org/ > (downloaded on August 2017).

HARTLEY, B. 1996. An atlas of British diatoms. Biopress Ltd. England, Bristol. $601 \mathrm{p}$.

Hein, M. K., B. Winsborough \& J. M. Suluivan. 2008. Bacillariophyta (diatoms) of the Bahamas. Gantner Verlag. Königstein, Germany. 303 p.

Jonathan, M. P., E. Shumilin, M.G. Rodríguez-Figueroa, P.F. Rodríguez-Espinoza \& S.B. Suлттн. 2016. Potential toxicity of chemical elements in beach sediments near Santa Rosalia copper mine, Baja California Peninsula, Mexico. Estuarine, Coastal and Shelf Science 180 (1): 91-96. DOI:10.1016/j.ecss.2016.06.015.

Licea, S., J. L. Moreno-Ruiz \& R. Luna. 2016. Checklist of diatoms (BaciIlariophyceae) from the Southern Gulf of Mexico: Data-Base (19792010) and new records. Journal of Biodiversity and Endangered Species 4 (3): 1-7. DOI:10.4172/2332-2543.1000174.

López-Fuerte, F. 0. \& D. A. Siqueiros-Beltrones. 2016. A checklist of marine benthic diatoms (Bacillariophyta) from México. Phytotaxa 283 (3): 201-258. D0I:10.11646/phytotaxa.283.3.1.

Mcheill, J., F. R. Barrie, W. R. Buck, V. Demoulin, W. Greuter, D. L. Hawksworth, P. S. Herendeen, S. Knapp, K. Marhold, J. Prado, W. F. Prud'homme Van Reine, G. F. Smith, J. H. Wiersema \& N. J. Turland. 2012. International Code of Nomenclature for algae, fungi, and plants (Melbourne Code), adopted by the Eighteenth International Botanical Congress, Melbourne, Australia, July 2011. Available on line: http://www.iapttaxon.org/nomen/main.php?page=title (downloaded on August 2017).

Peragallo, H. \& M. Peragallo. 1908. Diatomees marines de France et des districts maritimes voisins. M. J. Tempere. Grez sur Loing. 491 p.

Siquelros-Beltrones, D. A. 2002. Diatomeas bentónicas de la Península de Baja California; diversidad y potencial ecológico. Oceánides, CICIMAR-IPN \& UABCS. La Paz. 102 p. 
Siqueiros-Beltrones, D. A. \& U. Argumedo-Hernández. 2017. New records of benthic marine diatom taxa for Mexican littorals. CICIMAR-Oceánides 32 (1): 59-62.

Siqueiros-Beltrones, D. A., U. Argumedo Hernández, J. M. Murillo Jiménez \& A. J. Marmolejo Rodríguez. 2014. Diversidad de diatomeas bentónicas marinas en un ambiente ligeramente enriquecido con elementos potencialmente tóxicos. Revista Mexicana de Biodiversidad 85 (3): 1065-1085. DOl:10.7550/rmb.43748

Sterrenburg, F. A. S. 2000. Studies on the genera Gyrosigma and Pleurosigma (Bacillariophyceae). Gyrosigma reversum (Gregory) Hendey and G. naja (Meister) Sterrenburg, nov. comb. Proceedings of the Academy of Natural Sciences of Philadelphia 150 (1): 301-304. DOI:10.1635/0097-3157(2001)151[0121:SOTGPA]2.0.C0;2

Stidolph, S. R., F. A. S. Sterrenburg, K. E. L. Smith \& A. Kraberg. 2012. Diatom Atlas: U.S. Geological Survey Open-File Report 2012-1163. Available online at: http://pubs.usgs.gov/of/2012/1163/. pdf (downloaded on February 4, 2015).

Witkowski, A., H. Lange-Bertalot \& D. Metzeltin. 2000. Diatom flora of Marine coasts I. A.R.G. Gantner Verlag K.G., Ruggell. 925 p. 